УДК: $7.032(37)$

ББК: 85.113(0)32;85.118.7

A43

DOI: $10.18688 / \mathrm{aa} 188-8-68$

Th. N. Howe

\title{
A Most Fragile Art Object: Interpreting and Presenting the Strolling Garden of the Villa Arianna, Stabiae
}

The Stabiae archaeological site, like all sites in the area of the eruption of Vesuvius in 79 BCE, is remarkable for its vivid state of preservation. A series of six enormous sea-view villas (villae maritimae) stand on the edge of a $1.8 \mathrm{~km}$ long sea-cliff, three of which have been partly reexcavated and are open today, with walls standing to over a storey in height and with hundreds of square meters of high quality frescoes and floor mosaics excellently preserved. It is in fact the largest concentration of well-preserved large villae maritimae in the entire Mediterranean. Such villas which were clustered around the Bay of Naples in the Later Republic were not simply centers of luxury and wealth, but crucial centers of political power, just as were the senatorial domus clustered around the Forum Romanum. The senatorial domus in Rome, however, are poorly preserved, and so only at Stabiae is there the possibility for archaeology to recover the total environment of this critical historical elite Roman culture at the time of the transition from Republic to Empire.

It was these features of the Stabiae site, which is largely unencumbered by modern buildings, which launched the Restoring Ancient Stabiae project and the RAS Foundation in 1999 and 2002 in an effort to create a Master Plan $[15 ; 9 ; 8 ; 12 ; 10 ; 13]$ for assisting the Superintendancy Pompei in developing the site as a large, innovative archaeological park, featuring full excavation of three of the villas, conservation and shared site management.

The extraordinary preservation of the site presents extraordinary opportunities to recover the "total environment", but also presents extraordinary challenges. Some of the most significant aspects of the ancient villas were fragile and evanescent, two in particular, namely: patterns of movement between the villas and through the spaces of the villas of elite owners, elite guests and servile staff; and gardens.

The presence or absence of gardens makes a huge difference in the perception of the character of a peristyle court. If one compares the large piscine of the Villa A at Oplontis (supposedly of Poppaea Sabina) which originally was surrounded by trees (Fig. 1) to that of the Great Peristyle of the Villa San Marco at Stabiae (Fig. 2), where the plane trees have been replaced after the ancient pattern, the effect is radically different. Oplontis gives the effect of a parched desert. At the Villa San Marco, as one visits it today, the courtyard is shady and cool, and catches the sea breezes, just as Vitruvius recommends for orienting for cities [22, 1.6.1-1.6.8]; as one strolls along the porticus looking left and right, there is the interplay between the fictive painted garden 


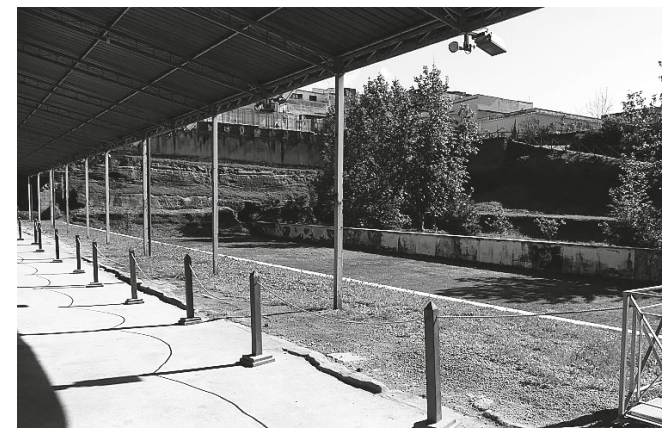

Fig. 1. The large Piscina at Oplontis Villa A (so-called villa of Poppaea Sabina). Photo by T.N. Howe

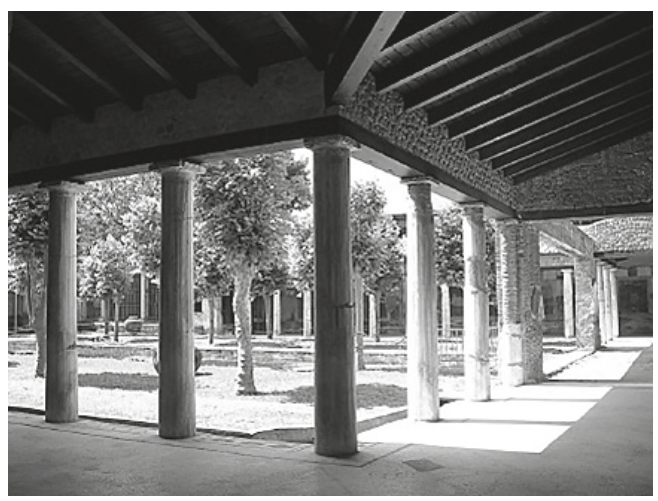

Fig. 2. The Great Peristyle at the Villa San Marco, Stabiae, with replanted plane trees. Photo by T.N. Howe in the frescoes to one side and the real garden to the other. The courtyard, even without the water features, is a functioning microclimate, always cooler than the surrounding areas, and is so by mastery of environmental and artistic design.

This paper presents the results of recent excavations and studies at Stabiae which have enhanced our knowledge of the simultaneous development in architecture, painting and gardening between ca. $30 \mathrm{BCE}$ and $79 \mathrm{CE}$, which may mark new relationships between architecture and views, and even the arrival of the landscape architect as well as architectural scene painter. Our discoveries also shed light on one of the most elusive aspect of ancient architecture: how elite and servile inhabitants may have moved through the villas in ways which enforced the social hierarchies and the villa as a political tool of the owners.

We know a great amount of how elite senatorials moved through the streets of Rome between domus and the Forum, followed by a cortege of clientes whose number was an indication of their status. We also know a great deal about the morning salutation, the descent into the Forum, the

importance of the evening cena with favored clientes and amici, all arranged hierarchically on triclinium couches, and the presence of politically knowledgable women of the house at the table, and therefore their involvement in the business and politics of the familia (summarized in $[14 ; 11])$.

We have less idea of the activity in the great villas of the of the villas of the senatorial and "municipal" elite (municipales, local town councilors who were the closest social equivalents to Roman senators in business and politics) (see: $[4,11,14]$ ). It is clear that in the late Republic they became seen as a useful political and social tool of the senatorial elite, and that they clustered in three areas: the horti immediately surrounding the hills above Rome; areas with sea or mountain views about a few hours ride from Rome, such as Tusculum and Laurentum; and around the Bay of Naples. The greatest villas of the Bay of Naples were on the north side, around Misenum, Baiae, Cuma and Puteoli, but they are very poorly preserved. At Stabiae an entire stretch of $1.8 \mathrm{~km}$ is preserved under the Vesuvian eruption layer and five or six villas and a small village (the pagus of Stabiae) are clustered on the edge of the sea-cliff directly next to one another. But, although the villas at Stabiae were begun ca. $80 \mathrm{BCE}$, most construction 
dates to the Augustan period or later. It is interesting to note that in Rome there is a significant change in the clustering of known senatorial domus in the Empire. Locations are mainly known from literary sources. In the Republic, in the era of competitive senatorial politics, they cluster mainly in the area of the Forum and the Palatine. But under the Empire, with the decline of truly public political activity on the part of the senatorials, they scatter over much of the City of Rome. Similarly in the course of the first and second centuries CE villas elsewhere in the countryside also tend to be more dispersed as opposed to be cluttered close to cities (summarized in [11]).

The actual arrangement of the clusters of villas at Misenum and Cuma in the late Republic is not known, or little knowable, because of poor preservation, but Stabiae seems to preserve the pattern of the competitive era of the later Republic into the period of the Empire: densely clustered panoramic villas arranged side by side along a choice section of sea coast. The reason why the pattern may have continued into the time when opulent competition with the emperor became dangerous may be that it was wagered to be useful to be close to the emperor and his new collections of villas on Capri.

The issue of how this elite used their villas is somewhat clouded by the myth or reality of otium. Otium ("leisure", but not "relaxation") prescribed a type of activity where one could pursue personal enrichment without the pressure of making urgent business decisions, which would be negotium (loosely "business"). According to this, the great maritime villas were places of retreat from the pressures of public business for the type of restorative leisure that was seen to be the entitlement of those who have the right and duty to rule, but there are a few indications that this was not completely so. Cicero complains that he often has to wear a toga and that his villa at Puteoli was so busy with visitors that it might have been a pusilla Roma, a little Rome (Cicero, Att. 5.2.2, 1.13; also see [14; 4, p. 48; 23, p. 5]). A remark from Pliny the Younger quips that he could see just how important his host thought each guest was by the menu in each dining room, which implies a gathering of several dining rooms at once. This author and Mantha Zarmakoupi have independently calculated the large villas like Arianna and San Marco at Stabia and the Villa of the Papyri at Herculaneum could have hosted as many as one hundred and fifty dinner guests $[14 ; 11 ; 24]$. One of the greatest pleasures for people like Cicero when visiting the Bay of Naples was the peregrinatio, or traveling around to visit several of the villas of other acquaintances in the Bay. One might suspect then that although the senatorials and other municipales did not operate as much sub conspectu populi, (under the intense gaze of the people) as at Rome, and that they may have operated more in concert and in competition with each other in terms of social display of culture and property, and that the villas at times served as venues for rather large social gatherings.

A certain amount is known about how elite and servile inhabitants in the large domus of the Vesuvian area moved through the architectural spaces. A general rule of thumb is that the elite generally moved from one large space to another-in other words always through large spaces-and the servile staff only moved through corridors, generally out of sight. One can see this in the House of the Menander at Pompeii as well as at the villas of Stabiae, with the recent exception shown by the Hermitage excavations at the Villa Arianna which demonstrated that there was a corridor which had fine quality frescoes which connected the main entrance peristyle of the elite area to the Thermal complex (Fig. 3) [14, pp. 135-139]. This corridor, 


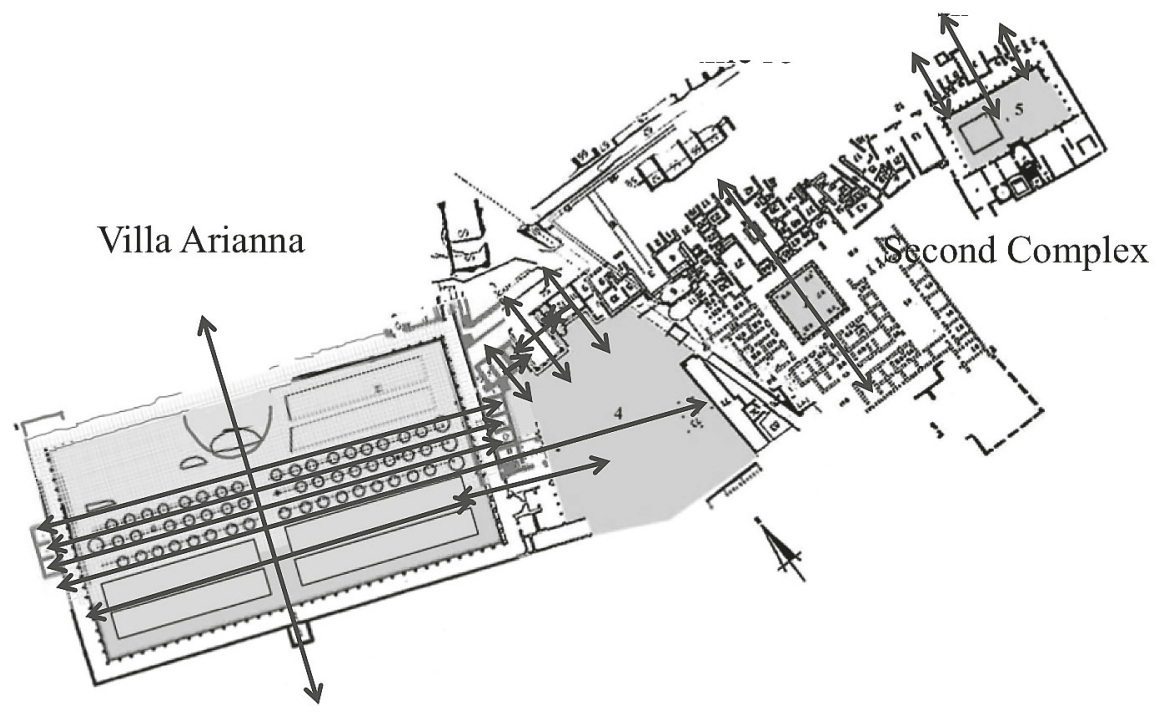

Fig. 3. The Villa Arianna, Stabiae, plan showing original "Durchblick" of the first phase of the villa, and the additional of multiple-view entertainment rooms in the $1^{\text {st }}$ century A. D. Plan by RAS Foundation

however, is a later addition to allow the Thermal complex to be added to the existing platform or "Durchblick" villa of ca. 80-60 BCE.

Other well-known design indications of movement or hierarchy of spaces. There is a hierarchy of status indicated by paint pigments, with cinnabar red (minimum, or mercury oxide) and Egyptian blue at the top, black on white for the bottom (the zebra stripes supposedly for servile areas) [23, pp. 17-64]. In areas of elite movement the decorations and vignettes tend to be partly repetitive, or ariations on a theme, such the pictures of lyrical villa landscapes in the roundels of the Great Peristyle of the Villa San Marco (Fig. 2), whereas the rooms where static entertainment is to take place (the triclinia) feature large history and mythological paintings and symmetrical architectural frames centered around the center bay of each wall.

It seems generally that the elite preferred to travel to villas by the comfort of boat when the weather was good (April - August) and the discovery of a ramp and private access to the sea at the Villa Arianna in 1988, and a descending street from the Villa San Marco, seem to confirm this as a primary approach (summarized in [14]). But recent excavations (2009-) at the Villa San Marco give another twist. The excavations right across the street in the small village / (pagus) of Stabiae revealed a narrow panoramic porticus of a large townhouse built directly over the out-of-use former city wall [20, pp. 177-239]. The situation at Stabiae was therefore the same that we have at Pompeii and Herculaneum, were the city walls go out of use after the end of the Civil Wars c. 30 B. C. and the properties are taken over by large townhouses which exploit the views of the Bay. Another twist is that the portal to the entrance courtyard of the Villa San Marco directly faces the entrance portal to the townhouse, and they are both framed by identical engaged Doricizing half-columns with canellations rendered in stucco. Furthermore, the street between the two descends to the presumed harbor and passes through 
the former city gate, which forms a connection between the two. The recent excavations reveal that the top of the former gate likely formed a bridge between the two, connecting the large panoramic peristyle of the townhouse with a large room (a presumed "palaestra") of the Villa San Marco.

Therefore, it is very possible that in their later phases the townhouse and the villa San Marco were part of a single property spanning the city gate. The parallel for this is the house of Gn. Calpurnius Piso (consul ca. $7 \mathrm{CE}$ ) who committed suicide in $20 \mathrm{CE}$ when it was obvious he was going to be condemned by Tiberius, and his heirs were punished by, among other things, breaking up and expropriating his two properties in Rome which were on either side of the Porta Fontinalis that were joined by a bridge [1]. The Porta Fontinalis spans the Via Flaminia as it enters the north side of Rome, where it rises up from the Campus Martius to cross the saddle between Capitoline and Quirinal. In other words, it spanned the major entrance to the city of Rome, a place more prominent than the later Palatine palaces. The conjoining of Villa San Marco and the townhouse must have had an equally imposing effect.

Recent studies demonstrate that the site of Stabiae can document the development of a "panoramic" sensibility in Roman villa architecture from ca. 80/60 BCE to 79 CE, featuring in particular the introduction of "multiple-view" entertainment rooms [11]. The Villa Arianna documents much of this process, with the early villa of ca. 80/60 BCE being a 'platform' villa with two units (peristyle and atrium), with a single view-axis from entrance to viewing terrace (the so-called "Durchblick," or "through-view") similar to the Villa of the Mysteries in Pompeii, with a single panoramic viewing area from the ostensible tablinum on the sea front (Fig. 3) [6, pp. 44-465]. Later additions, apparently from early first century CE, onward, feature rooms which, often in a single space, face the sea in front, the mountains behind, and sometimes, framed gardens, on either side.

The core of the original Villa Arianna is a traditional "Durchblick", a straight line-of-sight from entrance to peristyle to atrium to view. With the newer villas of post 30 B.C. (Villa San Marco) and the alterations to the Villa Arianna, movement tend to move not in the long straight line, but in a jogging fashion with abrupt transitions between spaces (Fig. 3). The elite continue to move from large space to another, avoiding corridors (with the exception of the one added at the Villa Arianna), but the routes are circuitous and each individual space will usually have a very strong cross-axial spatial orientation and frame very different views of nature. The spatial experience for elite movement is one of repeated surprise in isolated differential cross-axial spaces framing diverse views of nature.

The most significant recent discovery by excavations at Stabiae is the uncovering of an astonishingly well-preserved huge garden which seems to have been added to the Villa Arianna ca. 30 CE (Fig. 3) [16; 17]. About two-thirds of the garden, some $118 \mathrm{~m}$ long, was cleared, originally by the Superintendancy Pompei, ostensibly with the intention of stabilizing the fragile cliff by lessening the load of the $4 \mathrm{~m}$ overburden of the volcanic deposit of $79 \mathrm{CE}$. The garden is framed by a three-sided peristyle which opens to the view of the Bay of Naples with a semicircular tank on the central axis. This is what one can call differential cross-axial planning which develops in Roman sanctuaries of the later second and first centuries BCE. The main axis is the short axis, which is the same pattern that occurs in large complexes in Late Republican and Imperial architecture (Praeneste, Baths of Caracalla). 


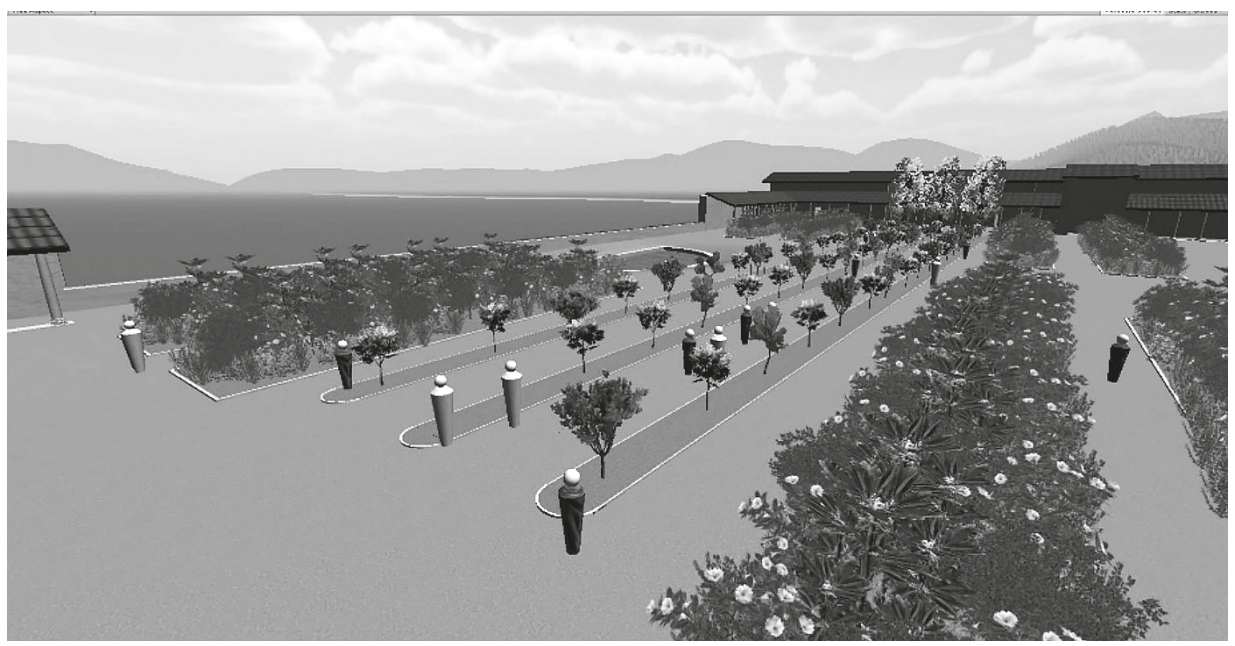

Fig. 4. Video reconstruction of movement of guests through the garden in the form of planting beds shown in the Villa of Livia, Prima Porta fresco. Video by Prof. K. Gleason and students, Cornell University

The planting beds of the garden were well-preserved and reveal that they consisted of: two side beds planted with an apparently irregular pattern of a variety of shrubs; and three long narrow beds planted with regularly spaced trees, all of different species: and walkways (ambulationes) between the beds. Phytoliths reveal they were planted with grass. Romans had lawns. This was clearly a garden meant to be walked in. There are even little bridges over the gutters from the peristyle. Smaller domestic gardens at Pompeii have barriers between the columns; these gardens are meant to be looked at, not walked in.

Analysis of the wider garden beds and comparing them with frescoes in Pompeii by garden archaeologist Prof. Kathryn Gleason of Cornell [17, pp. 67-89] revealed that these gardens are the first solid archaeological evidence of the existence of the type garden depicted in the famous garden fresco of the Villa of Livia at Prima Porta. At first this seems in both cases to be a sort of "fictive thicket," but further analysis of root cavities and frescoes suggest that the plants were carefully shaped in layers and mounded to the middle of the bed, and that they were miniaturized, likely allowing views over the tops to distant views, and to other strollers in the garden. The spatial experience of the garden is much the same as for the architecture: differential cross-axes framing very different views in all directions, here, to the Bay of Naples to the N., the Monti Lattari of the Sorrento peninsula to the S., the Appenines to the E. and the mountains and shore of the peninsula toward Capri toward the W.

Given the possibility that these villas may have on occasion hosted large entertainments for large numbers of elite persons, perhaps dining as many as one hundred and twenty persons at once all over the villa, the design of this garden seems intended to accommodate, and even manipulate, human interaction (Fig. 4). The ambulationes, with their axial and cross-axial framed views, and miniaturized orchards or "fictive thickets", allowing glimpses of the people in the other lanes and views beyond, allowed a multiplicity of interactions: one could choose to turn a corner and meet someone; turn a corner and avoid someone; walk behind, walk ahead, walk 


\section{$\rightarrow$ Provide for plant divers ity} Section

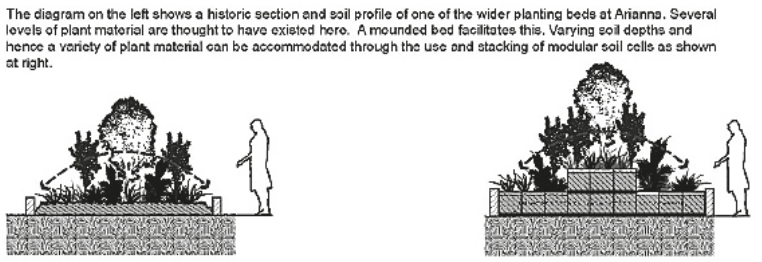

$\Rightarrow$ Visualization of Great Peristyle Replanted - Looking North

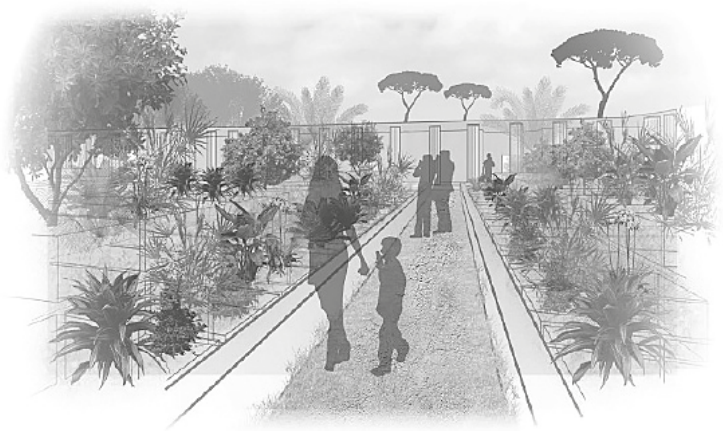

Fig. 5. Plan for conservation and reconstructed presentation of the garden of the Great Peristyle of the Villa Arianna. By Prof. K. Gleason and students, Cornell University

with, discuss the view, the meanings of the wall frescoes, current philosophical trends, or more likely, business and politics.

This was not a garden just for enjoying the framed views of the Bay of Naples; it was a garden for the elite of early Imperial Rome... to view each other, to meet each other, or to avoid each other.

Recreating this experience and preserving the evidence presents a special challenge to the presentation of the site. Still today gardens at Pompeii are rarely accurately reconstructed, if reconstructed at all, and if so, reconstructions frequently destroy the garden stratigraphy, which prevents further evaluation of the accuracy of the reconstruction. RAS Foundation partners from Cornell's department of Landscape Architecture have proposed preserving the beds, whose root cavities are now preserved by casts, by covering them with permeable eco-turf, and building planting beds on top (Fig. 5). The ambulationes can be replanted with lawn without major archaeological harm. This solution, while slightly distorting the original proportions by raising the planting beds, may be a reasonable compromise in order to recover with remarkable precision one of the most evanescent experiences of Roman antiquity: strolling in the garden of an elite and powerful Roman and experiencing the spatial interaction of views, nature... and other strollers. 


\section{References}

1. Bodel J. Punishing Piso. American Journal of Philology, vol. 120, no. 1 (spring, 1999), pp. 43-63.

2. Bonifacio G.; Sodo A.M. Stabiae, Guida Archelogica alle ville. Castellammare di Stabia, Nicola Longobardi Editore Publ., 2001. 216 p. (in Italian).

3. Camardo D., Ferrara D.A. (eds.). Stabiae dai Borbone alle ultime Scoperte. Castellammare di Stabia, Nicola Longobardi Editore Publ., 2001. 175 p. (in Italian).

4. D'Arms J. Romans on the Bay of Naples: A Social and Cultural Study of the Villas and Their Owners from 150 B. C. to A. D. 400. Cambridge, MA, Harvard University Press Publ., 1970. 252 p.

5. D’Orsi L. Gli scavi di Stabiae. Giornale di scavo. Ministero per i Beni Culturali ed Ambientali, Soprintendenza Archeologica di Pompei, Monografie, vol. 11, Castellammare di Stabia, Nicola Longobardi Editore Publ., 1996. 526 p. (in Italian).

6. Esposito D. Pompei, Silla e la Villa dei Misteri. Villas, maison, sanctuaires et tombeaux tardo-républicains: découvertes et relecteurs récentes, Actes du colloque international de Saint-Romain-en-Gal en l'honneur du Anna-Galina Zevi. B. Perrier (ed.). Rome, Edizione Quasar Publ., 2007, pp. 441-465 (in Italian).

7. Gardelli P.; Butyagin A. Stabiae. Villa Arianna. Relazione sulle due campagne di scavo e restauro 2012/2013 condotte dal Museo Statale Ermitage/Fondazione RAS. Rivista di Studi Pompeiani, 24. Roma, L'Erma di Bretschneider Publ., 2013, pp. 135-139 (in Italian).

8. Howe Th. N. Le opportunità per un parco archeologico sulle ville antiche di Castellammare di Stabiae. Conference on the occasion of the bi-sesquicentennial of the opening of excavations at ancient Stabiae, March 25-27, 2000. Castellammare di Stabia. Stabiae: Storia e Architettura. 250 Anniversario deglio Scavi di Stabiae, 1749-2001. G. Bonifacio; A. Sodo (eds.). Roma, L'Erma di Bretschneider Publ., 2002, pp. 189194 (in Italian).

9. Howe Th. N. Powerhouses: The Seaside Villas of Campania in the Power Cultures of Rome. In Stabiano: Exploring the Seaside Villas of the Roman Elite. Exhibition catalogue. T.N.Howe with Soprintendenza Archeologica di Pompei. Castellammare di Stabia, Nicola Longobardi Editrice Publ., 2004, pp. 95-104.

10. Howe Th. N. Restoring... and Digitally Archiving... Ancient Stabiae (lecture). CyArk 500 Challenge, Launch and Conference. The Tower of London, New Armouries Building, Oct. 20-22, 2013 Available at: https:// www.facebook.com/l/uAQE_BYYw/https\%3A\%2F\%2Fwww.youtube.com\%2Fwatch\%3Fv\%3DuXjAG2ytR bI\%26feature\%3Dc4-overview\%26list\%3DUUaRk0jIRJn2MPhHd7hVJw_A

11. Howe Th. N. The Architectural Evolution at the Villas of Stabiae, c. 80 B. C. - A. D. 79. Acts of the conference: Paradigm and Progeny: Roman Imperial Architecture and Its Legacy, Proceedings of a Conference Held at American Academy in Rome in Honor of William L. MacDonald, Dec. 6-7, 2011. F. Yegül; D. Favro (eds.). Journal of Roman Archaeology, Supplementary Series, no. 101, 2015, pp. 63-78.

12. Howe Th. N. Defining an Archaeological Park: The Restoring Ancient Stabiae Foundation Master Plan 2001 and Work Since 2007. $7^{\text {th }}$ International Conference on Contemporary Problems of Architecture and Construction. The Fruition of the Heritage: Cultural Value-Based Travel, Routes and Landscape. New Uses and Enhancement of Monuments. The Fondazione Romualdo di Bianco. The "Life Beyond Tourism" Project. Florence, Italy, November 19-21, 2015. S. Bertocci; P. Puma (eds.). Proceedings of the $7^{\text {th }}$ International Conference on Contemporary Problems of Architecture and Construction. Napoli, La Scuola di Pitagora Editrice Publ., 2015, pp. 701-706.

13. Howe Th. N. Stabiae: A Draught Sustainability Master Plan after the Model of Aerospace. Publication of the conference XXXIII Giornata dell'Ambiente: Resilienza delle città d'arte ai terremoti/Enhancing the Resilience of Historic Sites to Earthquakes, Accademia Nazionale dei Lincei Roma, 3-4 novembre, 2015. Atti dei Convegni, 306. Roma, Accademia Nazionale dei Lincei Publ., 2017, pp. 205-222.

14. Howe Th. N. Was Stabiae a Senatorial Enclave on the Bay of Naples? Roman Villas in the Mediterranean Basin: History, Archaeology, Art. An International Seminar at Mishkenot Sha'ananim, Jerusalem, December 16-17, 2008, organizers, to be published in the Acts of the conference. T.N.Howe; Y. Dromi (co-org.). G. Métraux; A. Marzano (eds.). New York, Cambridge University Press, 2018.

15. Howe Th. N.; Gardelli P. The Archaeological Park at Stabiae: a Regional Interdisciplinary and Sustainable Approach. Actual Problems of Theory and History of Art: Collection of articles, vol.5. S. V. Mal'tseva, E. Iu. Staniukovich-Denisova, A.V.Zakharova (eds.). Saint Petersburg, NP-Print Publ., 2015, pp.150-159. Available at: http://dx.doi.org/10.18688/aa155-1-14 (accessed 1 May 2018)

16. Howe Th. N.; Gleason K. L.; Sutherland I. Stabiae, Villa Arianna: scavi e studi nel giardino del Grande Peristilio, 2007-2011. Rivista di Studi Pompeiani, Notiziario, 22. 2013, pp. 205-209. 
17. Howe Th. N.; Gleason K.; Palmer M.; Sutherland I. (eds.). Excavation and Study of the Garden of the Great Peristyle of the Villa Arianna, Stabiae, 2007-2010. Rivista di Studi Pompeiani, Quaderni, VII. Associazione Internazionale di Amici di Pompei. Castellammare di Pompei, Nicola Longobardi Editrice Publ., 2016. $138 \mathrm{p}$.

18. Jashemski W. Gardens of Pompeii, Herculaneum, and the Villas Destroyed by Vesuvius, vol. 1. New Rochelle, New York, Caratzas Bros. Publ., 1979. 372 p.

19. Marzano A. Roman Villas in Central Italy. A Social and Economic History. Leiden; Boston, A. J. Brill Publ., 2007. $823 \mathrm{p}$.

20. Ruffo F. L'insula sud-occidentale del cosidetto "impianto urbano" a Stabiae. Nuovi date dalla recente campagna di scavo. Oebalus, 2010, no. 5, pp. 177-239 (in Italian).

21. Stackelberg K., von. The Roman Garden: Space, Sense and Society. London; New York, Routledge Publ., 2009. $182 \mathrm{p}$.

22. Vitruvius. Ten Books on Architecture. I. D. Rowland (transl.); T. N. Howe (commentary \& illustrations). New York, Cambridge University Press Publ., 1999. 352 p.

23. Wallace-Hadrill A. Houses and Society in Pompeii and Herculaneum. Princeton, NJ, Princeton UP Publ., 1994. $224 \mathrm{p}$.

24. Zarmakoupi M. Designing for Luxury on the Bay of Naples: Villas and Landscapes, (c. 100 BCE - 79 CE). Oxford Studies in Ancient Culture and Representation. Oxford, Oxford University Press Publ., 2014. 315 p.

Title. A Most Fragile Art Object: Interpreting and Presenting the Strolling Garden of the Villa Arianna, Stabiae.

Author. Thomas Noble Howe - coordinatore generale/scientific director, Fondazione Restoring Ancient Stabiae. Castellammare di Stabia, Italy; professor of Art and Art History, Chair of Art History, Dept. of Art and Art History, Southwestern University, Georgetown, TX, USA. howet@southwestern.edu

Abstract. In 2007 the Superintendancy of Pompei and the Restoring Ancient Stabiae Foundation uncovered an enormous formal garden in the so-called Villa Arianna at Stabia, near Pompeii, some $113 \mathrm{~m}$ long, in an excellent state of preservation. The soil surfaces were as excellently preserved as they had been on the morning of the $24^{\text {th }}$ of August, 79 CE: the surfaces of what had been grassy walkways (ambulationes); planting beds for shrubs (viridia); and lines of trees of many species. Root cavities preserved root forms down to the size of hair roots.

From 2007 to 2012 the Restoring Ancient Stabiae Foundation and its many collaborators assumed the final excavation and study of the garden surface, which is in final stages of publication. The result is that the study of this most ephemeral of archaeological art objects - an ancient garden - has demonstrated that highly innovative developments in the Later Republic and Early Empire in architecture, painting and poetry parallel and are paralleled by innovations in garden design. Without the garden, one cannot interpret the architecture.

Analysis of the garden surfaces, especially by Kathryn Gleason and her team from Cornell, revealed that the beds of shrubs are the first archaeological evidence ever found for the type of miniaturized rustic garden seen in the famous fresco of the Villa of Livia at Prima Porta. The rows of trees are all formally aligned but of different species, like a zoological gazetteer of empire. The arrangement of plants creates the same type of "differential cross-axial" experience of near space and distant views that architects were creating in the architecture of the early Empire. Hence the garden is planted with the professional skill for special manipulation of space that heralds the arrival of the professional landscape architect (topiarius). This art was not only the manipulation of space but also of the people who moved through those spaces. The elite in the Roman mansion normally moved through wide spaces which connected to one another, and the servile class moved through corridors and stood semi-invisibly in the shadows. But our analysis, illustrated by digital reconstructions and videos, shows that the large formal garden of the Villa Arianna was meant to be walked in, and its design allowed for all sorts of viewing, of encounters, and of avoidance of encounters. This was a place where people of great power and privilege came to interact, largely out of view of conspectus populi, but to interact, under the control of the host/ dominus and hostess/domina.

Without this knowledge about the garden, the interpretation and visit to the great villas of the Bay of Naples is like visiting an empty, lifeless shell. This paper will present non-destructive approaches to recreating much of the effect of this garden that is being proposed by the Restoring Ancient Stabiae Foundation, whose mission is to assist the Superintendancy of Pompei in creating a large archaeological park on the site of the villas of Stabiae.

Keywords: Roman villas; Stabiae; Villa Arianna at Stabia; Villa of Livia; Prima Porta; the Restoring Ancient Stabiae Foundation; Superintendancy of Pompei; Gulf of Naples; villa maritima; archaeological park; 
conservation of archaeological sites; garden and park landscape art; landscape design; panoramic villas/views; architecture of Classical antiquity; antique gardens; Roman gardens.

Название. Самый хрупкий арт-объект: интерпретация и представление сада для прогулок на вилле Ариадны в Стабиях.

Сведения об авторе. Хоу Томас Нобл - профессор, заведующий Кафедрой истории искусства Университета Саутуэстерн в Джорджтауне, шт. Техас, США; главный координатор и научный директор Фонда реставрации древних Стабий, Кастелламаре ди Стабиа, Италия. howet@southwestern.edu

Аннотация. В 2007 г. исследованиями Главного управления по делам Помпей и Фонда реставрации древних Стабий был обнаружен огромный регулярный сад на так называемой вилле Ариадны в Стабиях близ Помпей. В длину его протяженность составляла порядка $113 \mathrm{~m}$, а состояние сохранности оказалось великолепным. Почвенный покров сохранился настолько хорошо, как будто был таким же в роковое утро 24 августа 79 г. Сохранилась поверхность участков, некогда бывших травяными прогулочными дорожками, кустарниковые клумбы (virdia) и аллеи из деревьев разных видов. В полостях, где прежде находилась корневая система, формы корневых ответвлений сохранились вплоть до самых тончайших. С 2007 по 2012 г. Фонд реставрации древних Стабий и его партнеры полностью раскопали и исследовали все поверхности сада. Результаты этих работ, находящиеся в завершающей стадии подготовки публикации, показывают, что исследование древнего сада - этого самого эфемерного из археологически найденных произведений искусства - добавляет к новейшим достижениям в области изучения архитектуры, живописи и поэзии сведения о садово-парковом искусстве и дизайне периода поздней Республики и ранней Империи. Без садов невозможен и анализ архитектуры.

Анализ поверхности садов, предпринятый Кэтрин Глэзон (Kathryn Gleason) и группой ее коллег из Корнелла, показал, что обнаруженные кустарниковые клумбы - это первое и единственное в своем роде археологическое свидетельство такого типа сельского сада, который в миниатюре был известен по знаменитому изображению на фреске из виллы Ливии в Прима Порта. Ряды деревьев были высажены регулярно, но это были деревья разных пород, образуя своего рода географический справочник империи. Распределение растений образует тот же характерный тип «поперечно-осевых» посадок на ближнем и отдаленном от построек пространстве, который был присущ архитектуре ранней Империи. Таким образом, сад засажен вполне профессионально, с мастерски организованным пространством, что указывает на грядущее появление специальной должности ландшафтного архитектора (topiarius). Искусство ландшафтного дизайна способствовало не только самой организации пространства, но и организации движения людей в этом пространстве. Представители высшего сословия обитателей дома обычно ходили по связанным между собой обширным помещениям, а представители обслуживающего класса ходили по коридорам или стояли полускрытые тенью. Наше исследование, проиллюстрированное цифровыми реконструкциями и видеоматериалами, показывает, что в большом регулярном саду виллы Ариадны был спланирован вход, а его планировкой в целом были предусмотрены как разные варианты созерцания красивых видов, а также возможности организации встреч или, наоборот, способов их избегать. Это было место, куда представители высшей власти и обладатели различных привилегий приходили для общения, причем большей частью с целью находиться вдали от посторонних глаз, на деле же - под надзором хозяина и хозяйки (dominus и domina). Без знания архитектуры и устройства садов понимание и даже само посещение больших вилл побережья Неаполитанского залива подобно визиту в пустую безжизненную скорлупу. Автор рассказывает о тех щадящих, не разрушающих памятник подходах к его изучению и воссозданию большей части эффектов сада, которые были предложены Фондом реставрации древних Стабий. Миссия Фонда состоит в том, чтобы оказывать всяческую поддержку Главному управлению по делам Помпей в создании большого археологического парка на территории стабианских вилл.

Ключевые слова: римские виллы; Стабии; вилла Ариадны; вилла Ливии; Прима Порта; Фонд реставрации древних Стабий; Главное управление по делам Помпей; Неаполитанский залив; приморские виллы; археологический парк; реставрация и охрана археологического объекта; садово-парковое искусство; ландшафтный дизайн; панорамные виллы/виды; античная архитектура; античные сады; римские сады. 